\title{
STIGMA PEREMPUAN LAJANG DAN PERKAWINAN DALAM METROPOP 90 HARI MENCARI CINTA KARYA KEN TERATE
}

\author{
SINGLE WOMEN AND MARRIAGE STIGMA \\ IN METROPOP 90 HARI MENCARI CINTA BY KEN TERATE
}

\author{
Tania Intan, Susi Machdalena \\ Jalan Raya Bandung-Sumedang Km 21, Jatinangor, Sumedang, Jawa Barat \\ Universitas Padjadjaran \\ Ponsel: 081285319071; Pos-el: tania.intan@unpad.ac.id
}

\begin{abstract}
Abstrak
Budaya patriarki telah membuat perempuan didorong untuk bersegera menjadi istri dan ibu dalam sebuah keluarga, sehingga ia lebih dihargai sebagai anggota masyarakat yang utuh. Fenomena ini masih berlangsung dalam situasi aktual, sebagaimana tercermin dalam sejumlah novel populer. Penelitian ini bertujuan untuk mempelajari stigma perempuan lajang dan perkawinan di dalam metropop 90 Hari Mencari Suami (2019) karya Ken Terate. Metode yang digunakan dalam penelitian ini adalah deskriptif-kualitatif. Data berupa kata, frasa, dan kalimat dikumpulkan dengan teknik simak-catat. Data selanjutnya diklasifikasi, diinterpretasi, dan dikaji. Landasan teoretis yang digunakan dalam penelitian ini adalah perspektif sosiologis dan kritik sastra feminis dari Beauvoir dan Humm. Hasil penelitian menunjukkan bahwa dalam novel 90 Hari Mencari Suami: (1) kelajangan merupakan hal yang tidak wajar terjadi pada perempuan dewasa sehingga muncul mitos dan stigma yang mendorongnya untuk segera menikah. Protagonis perempuan membuktikan bahwa mitos itu tidak benar dan memutuskan untuk menentukan jalan hidupnya sendiri. (2) Perkawinan tidak seharusnya terjadi karena perasaan takut melainkan didasari oleh kesadaran penuh untuk menjalaninya. Perkawinan yang ideal adalah yang memposisikan perempuan dan laki-laki dalam kedudukan setara.
\end{abstract}

Kata-kata kunci: stigma; perempuan lajang; perkawinan; metropop

\section{Abstract}

The patriarchal culture has encouraged women to immediately become wives and mothers in a family so that they are more valued as members of the whole society. This phenomenon is still taking place in actual situations, as reflected in several popular novels. This study aims to study the stigma about single women and marriages in Ken Terate's 90 Hari Mencari Suami (2019). The method used in this research is descriptivequalitative. Data in the form of words, phrases, and sentences were collected using notetaking technique. The data are then classified, interpreted, and reviewed. The theoretical basis used in this study is a sociological perspective and feminist literary criticism from Beauvoir and Humm. The results showed that: in the novel 90 Hari Mencari Suami: (1) singleness is something that is not natural for adult women so that 
myths and stigma emerge that encourage them to get married. The female protagonist proves that the myth is untrue and decides to decide her path in life. (2) Marriage should not occur out of fear but with full awareness of living it. The ideal marriage is one that positions women and men in an equal position.

Keywords: stigma; single women; marriage; metropop

\section{Pendahuluan}

Seperti chick-lit, metropop merupakan karya populer kontemporer yang kerap mengusung tentang perempuan. 'Metropop' sendiri merupakan istilah yang diciptakan oleh penerbit Gramedia sejak tahun 2010-an untuk menandai salah satu jenis terbitannya, yang cenderung mengangkat permasalahan kehidupan masyarakat kota, baik yang berkaitan dengan pekerjaan, percintaan, pertemanan, dan keluarga. Berbeda dengan chick-lit yang hampir selalu diakhiri dengan sekuen bahagia, akhir dari metropop cenderung realistis dan dewasa. Alurnya pun lebih sulit ditebak.

Karena lebih banyak dibaca oleh perempuan dan ditulis oleh perempuan, metropop kerap berfokus pada permasalahan perempuan dalam latar urban, termasuk kelajangan. Aksentuasi atas keberadaan protagonis perempuan heteroseksual yang lajang dalam budaya populer jelas terlihat sejak pertengahan tahun 1990. Novel Sex and the City (1997) karya Candace Bushnell misalnya, menunjukkan perayaan atas kelajangan dengan demografi tertentu (berkulit putih, stabil secara ekonomi, dan heteroseksual). Demikian pula halnya dengan novel Bridget Jones 's Diary (1996) karya Helen Fielding dan rangkaian chick-lit lainnya, yang memunculkan pola baru penokohan fiksi perempuan yang kemudian disebut TWITS (Teenage Women in their 30s) (Taylor, 2012: 1). Taylor juga menjelaskan bagaimana menguatnya fenomena kelajangan ditampilkan sebagai 'cultural obsession' oleh Dux \& Simic, atau 'new cultural affirmation' oleh Macvarish.

Dalam konteks Indonesia, kelajangan dimaknai secara situasional dan kultural. Yang lebih banyak muncul dari dunia fiksi kontemporer justru adalah tema tentang perempuan lajang yang terdesak untuk menikah karena tuntutan sosial. Tema tersebut ternyata tidak eksklusif dan telah banyak dieksplorasi, seperti di dalam novel 30 Hari Mencari Cinta (2004) karya Nova Riyanti Yusuf, Cinta Suci Zahrana (2011) karya Habiburrahman El Shirazy, OTW Nikah 
(2019) karya Asma Nadia, Kebelet Nikah (2020) karya Anisa Hakim, serta GanjilGenap (2020) karya Almira Bastari. Berulangnya penggunaan tema yang sama dalam karya-karya ini menunjukkan masih relevannya permasalahan tersebut dalam kehidupan perempuan Indonesia. Keberadaan perempuan lajang dengan stigmatisasi terutama sebagai sosok 'pengganggu rumah tangga/pelakor' atau malah sebagai 'perempuan aneh' merupakan isu yang kerap dikembangkan di dalam karya fiksi (T. Intan, 2021).

Selain karya-karya yang telah disebutkan di atas, novel lain yang mengusung tema tersebut dan telah dipilih sebagai objek penelitian ini adalah 90 Hari Mencari Suami (2019) yang merupakan karya pertama penulis Ken Terate pada lini metropop. Novel ini dipilih sebagai bahan kajian karena merupakan karya yang relatif baru, menggunakan gaya penulisan dan bahasa yang nyaman dibaca, mengandung unsur humor, dan memiliki akhir cerita yang tidak mudah ditebak. Karya tersebut, sebelum terbit sebagai buku, sempat diunggah penulisnya pada platform online Wattpad.

Novel yang terdiri dari 365 halaman tersebut diawali dengan sebuah epilog untuk memperkenalkan tokoh utama perempuan, Eli, beserta mimpi-mimpinya yang tidak tercapai hingga usianya yang menjelang tiga puluh tahun. Ia memiliki banyak harapan, yang salah satu di antaranya adalah saat usianya mencapai 28 tahun, ia akan "menikah dengan tunangan yang tampan dan miliarder itu" (hlm. 7). Namun kenyataannya, Eli belum juga menikah dan bahkan tidak memiliki pacar saat memasuki usia 29 tahun.

Kegalauan yang dialami protagonis tersebut agaknya dialami oleh banyak perempuan yang telah memasuki usia kepala tiga tapi belum menikah. Situasi ini diperparah ketika perempuan dihadapkan pada tekanan dari keluarga dan stres akibat pekerjaan (Wijayanti, 2019). Karena kerap menghadapi ketidakadilan, biasanya akan muncul kesadaran dan kekuatan pada perempuan untuk menuntut haknya dan mengupayakan hal yang dikehendaki sesuai dengan pilihannya (untuk menikah atau melajang). Kesadaran tersebut, menurut Widianti (2020: 54-55), diperoleh melalui pergaulan dan pendidikan yang membuat perempuan menjadi kritis dalam bersikap.

\section{Landasan Teori}

Pada umumnya, perempuan dewasa yang menunda pernikahan terhalang karena belum menemukan pasangan yang tepat, namun ada juga yang memang 
memilih untuk tetap melajang (Septiana, 2013: 72). Hurlock (1990) menjelaskan bahwa pada usia dua puluhan, tujuan hidup sebagian besar perempuan adalah menikah. Namun, bila perempuan belum juga menikah pada umur tiga puluh tahun, mereka akan mengganti tujuan dan nilai hidupnya untuk mulai berorientasi pada pekerjaan, karir, dan kesenangan pribadi. Perempuan berusia 30-an memasuki fase usia kritis (critical age) karena berada pada persimpangan antara pilihan ingin tetap menikah atau justru tetap menjadi lajang.

Kehidupan lajang pada perempuan memang tidak pernah bebas dari tekanan masyarakat yang dominan (Septiana, 2013: 72). Masyarakat Indonesia merupakan bagian dari struktur budaya Asia yang memiliki kecenderungan kolektivitas lebih kental dibandingkan dengan masyarakat Amerika atau Eropa. Oleh karena itu, anggota masyarakat Indonesia, terutama perempuan, mengalami tekanan yang jauh lebih kuat untuk memelihara norma budayanya, termasuk menikah. Pernikahan adalah salah satu ritus budaya yang sangat dihargai oleh hampir seluruh etnis budaya di Indonesia. Sebagai konsekuensinya, orang dewasa yang masih lajang, terlebih perempuan, akan mendapatkan tekanan dari orang tua dan lingkungannya untuk segera menikah.

Menurut teori Identitas Sosial dari Tajfel \& Turner yang dikutip Septiana (2013: 73), perempuan lajang menjadi kategori sosial tersendiri yang dilekati karakteristik khas bernada negatif atau 'tidak normal', karena dibandingkan dengan kelompok perempuan yang telah menikah dan dipandang 'normal'. Tindakan mengategorisasi ini memunculkan nilai psikologis yang berdampak pada harga diri individu yang masuk dalam kelompok tersebut. Status belum menikah pada perempuan dewasa akan cenderung diposisikan sebagai inferior karena tidak sesuai dengan norma kewajaran. Dengan status tersebut, individu yang mendapat identitas negatif, atau disebut juga stigma, akan merasakan adanya ancaman identitas.

Stigma sendiri, menurut Goffman, adalah semua bentuk kualitas yang bersifat fisik, sosial, atau personal yang membuat kelompok orang yang memilikinya dilabeli dengan identitas yang mendiskreditkan dan inferior (Septiana, 2013: 73-74). Dalam konteks ini, status 'perempuan lajang' mendapat penilaian yang merendahkan, sebagaimana ditunjukkan dalam kajian Indriana yang dikutip Septiana (2013: 74), 
perempuan lajang cenderung berkarakter tertutup, emosional, kekanak-kanakan, dan mudah marah. Penelitian Greitemeyer (2009) mengargumentasikan bahwa secara sadar, masyarakat menunjukkan sikap negatif pada para lajang, terutama perempuan. Mereka yang telah 'cukup umur' namun belum menikah ini mendapatkan label seperti: kurang dapat mengemban tanggung jawab, kurang dewasa, dan kurang pandai bergaul. Mereka juga sering diposisikan sebagai 'berbeda', bermasalah dalam menjalin hubungan intim, atau bahkan mengalami 'disfungsi pribadi' sehingga perlu mendapatkan intervensi pengobatan. Bahkan, Mami \& Suharnan (2015: 216) menemukan bahwa perempuan dalam kategori ini kerap dilabeli 'perawan tua', 'tidak laku', 'terlalu pemilih', dan 'suka jual mahal'.

Dalam kajian Major dan O'Brien (2005), ada dua strategi umum yang dapat dipilih oleh individu atau kelompok sosial yang menjadi target stigma. Cara pertama adalah vokasional, yaitu cara yang melibatkan usaha untuk menyelesaikan. Adapun cara kedua, non-vokasional, adalah cara yang tidak melibatkan usaha untuk menyelesaikan, seperti menyembunyikan status atau menghindar dari situasi yang mendatangkan stigma.
Dalam konteks novel 90 Hari Mencari Suami yang dikaji, telah tersirat melalui judul, bahwa protagonis memilih cara pertama, vokasional, dengan melakukan berbagai upaya dalam jangka waktu tertentu (90 hari) demi mendapatkan pasangan.

Dalam perspektif gender, tuntutan untuk menikah pada perempuan dewasa memang jauh lebih kuat daripada lakilaki. Laki-laki dewasa dianggap memiliki pilihan untuk menunda menikah dengan alasan sedang merintis atau mengembangkan kariernya. Sebaliknya, perempuan dewasa didorong untuk segera menjadi istri dan ibu dalam sebuah keluarga agar ia dihargai sebagai anggota masyarakat sepenuhnya. Perkawinan sendiri sebenarnya merupakan alat yang digunakan oleh laki-laki untuk mengendalikan perempuan (Beauvoir, 2016: 257). Perkawinan dan perempuan dikonstruksi sebagai dua sisi yang tidak dapat dipisahkan. Oleh karena itu, stigma negatif akan melekat pada perempuan lajang, sekalipun ia memiliki prestasi dan latar belakang yang baik. Perkawinan, menurut Humm (2007: 266), tidak lain merupakan tempat kategori gender direproduksi, tempat pembagian kerja secara seksual dan subordinasi 
perempuan, serta model institusi sosial lainnya mengenai norma seksual.

Kajian terdahulu tentang kelajangan perempuan dalam novel di antaranya telah dilakukan oleh Fahmi dan Arfiyanti (2020) yang mengkaji kesetaraan gender dalam novel Cinta Suci Zahrana karya Habiburrahman El-Shirazy. Temuan dari penelitian tersebut adalah adanya kecenderungan pada perempuan lajang yang berpendidikan dan berkarier tinggi mendapat desakan untuk segera menikah. Hal ini terjadi karena kuatnya budaya patriarki yang memiliki kehendak untuk menempatkan perempuan (kembali) ke ranah domestik. Sebaliknya, laki-laki memiliki keleluasaan untuk melajang karena dianggap memiliki hak untuk memilih.

Ketertarikan peneliti pada isu-isu feminis, terutama tentang kelajangan perempuan, dalam karya fiksi kontemporer ditunjukkan dengan beberapa publikasi. Sebagai contoh, novel karya Netty Virgiantini berjudul Cincin Separuh Hati dikaji oleh Intan dan Prayoga (2021) melalui strategi kebertahanan perempuan lajang dengan pendekatan psikologi sastra. Kajian ini menunjukkan bahwa trauma di masa lalu dapat menjadi penyebab perempuan melajang. Akibat pilihannya untuk melajang, perempuan rentan dikenakan stigma sebagai perempuan yang tidak laku, pemilih, memiliki orientasi seksual berbeda, serta berpotensi merusak rumah tangga orang lain. Namun, meskipun pada awal cerita ditunjukkan tokoh utama memegang janji selibat (tidak akan menikah untuk selamanya), pada akhirnya ia menikah juga. Realita ini menyiratkan kepatuhan perempuan pada nilai-nilai tradisional tentang lajang dan pernikahan.

Penelitian juga dilakukan terhadap karya Netty Virgiantini lainnya yaitu Jodoh Terakhir (T. Intan, 2021). Pokok permasalahan yang menjadi fokus adalah mekanisme perjodohan yang ditimpakan pada perempuan lajang. Telaah dengan pendekatan sosiologi sastra tersebut menunjukkan hasil bahwa ada resistensi sekaligus negosiasi dari tokoh perempuan dalam menghadapi perjodohan. Kecurigaan awal bahwa teks akan bertendensi feminis tidak terbukti, karena (lagi-lagi) tokoh perempuan patuh pada konstruksi sosial yang ditanamkan melalui struktur keluarga.

Hasil telaah yang relatif berbeda ditunjukkan Intan (2020) yang mengkaji resiliensi perempuan lajang dalam metropop Ganjil-Genap karya Almira Bastari. Analisis dengan kritik sastra feminis terhadap karya tersebut 
memperlihatkan bagaimana institusi perkawinan masih didambakan oleh tokoh perempuan yang mandiri, mapan, dan logis. Dalam menghadapi tanggapan negatif dari sekitarnya, protagonis yang merupakan lajang dewasa menampilkan perilaku resilien dan pencapaian yang dihasilkannya adalah mengubah posisinya dari objek menjadi subjek. Perkawinan tidak menjadi akhir dari novel bermuatan perspektif feminis tersebut.

\section{Metode Penelitian}

Metode yang digunakan dalam penelitian ini adalah deskriptif kualitatif. Data terdiri dari kata, frasa, dan kalimat yang dikutip dari objek formal penelitian dikumpulkan dengan teknik simak catat. Data selanjutnya diklasifikasi berdasarkan permasalahan, diinterpretasi, dan dianalisis.

Sesuai dengan permasalahan tentang perempuan lajang dan perkawinan yang menyentuh ranah ilmu sosiologi dan feminisme, maka pendekatan yang digunakan dalam penelitian ini adalah sosiologi sastra dan kritik sastra feminis.

Kritik sastra feminis digunakan karena teks yang ditelaah merupakan novel metropop yang ditulis perempuan, dibaca perempuan, dan membicarakan terutama tentang perempuan. Wiyatmi
(2012: 11) mengutip Ruthven, yang menyatakan bahwa kritik sastra feminis bersifat revolusioner karena memiliki tujuan menumbangkan wacana dominan yang diciptakan suara tradisional dan patriarkis.

Wiyatmi (2012: 30) juga mengutip Showalter yang memaparkan dua jenis kritik sastra feminis, yaitu kritik yang melihat perempuan sebagai pembaca dan kritik yang melihat perempuan sebagai penulis. Untuk penelitian ini, akan digunakan kritik sastra yang melihat perempuan sebagai pembaca, karena kritik ini berfokus pada citra dan stereotip perempuan dalam sastra, serta pengabaian dan kesalahpahaman tentang perempuan. Perempuan dalam karya sastra hampir selalu ditempatkan sebagai korban, bersifat sentimental dan memiliki kepekaan spiritual di bawah dominansi laki-laki (Djajanegara, 2003: 7).

\section{Pembahasan}

Bagian pembahasan ini dibagi menjadi tiga bagian yaitu: (1) Sinopsis Metropop 90 hari Mencari Suami, (2) Representasi Perempuan Lajang di antara Karir dan Stigma, dan (3) Perkawinan dalam Perspektif Perempuan. 


\subsection{Sinopsis Metropop 90 Hari Mencari Suami}

Novel ini dikisahkan melalui sudut pandang Eli sebagai narator-tokoh. Dengan karakter naratif ini, sifat penceritaan menjadi subjektif, intim, dan seperti pengakuan. Latar cerita didominasi oleh situasi kota Jakarta yang sibuk dan para tokoh ditempatkan dalam ruang kerja metropolis, yang melibatkan para pekerja dari dunia hiburan seperti artis, make up artis, manager artis, event organizer, penata gaya, dan wartawan. Latar cerita beralih ke Jogjakarta karena Eli memutuskan untuk mengundurkan diri dari pekerjaannya dan memulai hidup baru.

Pada awal novel, Eli memaparkan kegagalan mimpi-mimpinya untuk sukses sebelum berumur 30 tahun, terutama karena ia belum menikah. Ia bekerja sebagai sebagai asisten artis di sebuah perusahaan dengan atasan yang tidak ia sukai dan tidak menyukainya. Eli bertahan bekerja di tempat itu karena sesuai dengan passion-nya dan gajinya memungkinkan dirinya berbelanja online setiap kali ia merasa tertekan.

Kenyamanannya berubah menjadi kegelisahan saat ia memasuki usia 29, yang berarti satu tahun lagi menuju 30 tahun. Kepanikan Eli bertambah saat adik perempuannya menyatakan akan segera menikah. Dalam budaya Jawa, ada mitos bahwa jika 'dilangkahi', kakak perempuan akan mengalami kelajangan selamanya. Eli sebenarnya tidak yakin apakah dia ingin menikah atau tidak. Akan tetapi, ia tidak ingin menua sendiri. Untuk mendahului pernikahan adiknya, ia pun bertekad menemukan suami dalam waktu kurang dari 90 hari. Kabar buruk berikutnya tiba-tiba menghampiri, ketika Tristan, adik laki-lakinya, mengabari Eli bahwa ia akan segera melamar pacarnya.

Panik karena akan dilangkahi menikah oleh kedua adiknya, Eli pun membicarakan permasalahan itu dengan kedua sahabatnya, Sandra dan Rosa. Mereka pun merancang sejumlah langkah untuk segera menemukan suami bagi Eli. Meskipun selalu disibukkan dengan pekerjaan, Eli sendiri tetap berupaya menemukan laki-laki idamannya. Ia pergi ke tempat fitnes dan memainkan aplikasi pencari jodoh, Tinder. Ia juga menemui Jay, kakak angkatannya dulu saat kuliah yang sangat rupawan dan ramah. Eli pun sempat berhubungan dengan Dewa yang metroseksual dan mapan. Namun, tidak satu pun dari laki-laki yang ia temui yang benar-benar cocok dengannya.

Persahabatannya dengan Sandra dan Rosa memberi Eli pandangan baru tentang arti pernikahan. Sandra sudah menikah 
dengan seorang ekspatriat dan hidup berkecukupan secara material, tetapi tidak merasa bahagia. Demikian pula dengan Rosa, yang hamil tapi tidak dapat meminta pertanggungjawaban dari ayah bayi yang dikandungnya karena telah beristri. Eli juga banyak belajar dari hubungan Pak Dion dan Bu Mimi, yang merupakan kliennya.

Pada akhirnya, perjalanan hidup mendekatkan Eli pada Dimi, teman kecil dan tetangganya saat di Jogjakarta, dan membuat mereka menikah. Laki-laki sederhana itu awalnya tidak masuk kriterianya sama sekali. Namun, seiring waktu, Eli menyadari bahwa Dimi adalah orang yang tepat untuk menua bersamanya.

\subsection{Representasi Perempuan Lajang di antara Karir dan Stigma}

Eli adalah perempuan berumur hampir tiga puluh tahun. Penampilannya menarik dan mandiri secara finansial karena ia bekerja sebagai asisten artis di perusahaan Glow Event Company. Kesukaannya pada pekerjaan itu membuatnya terlena dan hampir lupa pada pernikahan, kalau saja Lisa, adiknya yang baru berusia 23 tahun, tidak menyatakan akan segera menikah. Eli pun menyadari bahwa dirinya tidak mau 'dilangkahi'. namun saat itu ia tidak sedang menjalin hubungan percintaan dengan siapa pun.
Selama ini, hubungan yang dijalaninya selalu berakhir dalam waktu relatif singkat.

Aku juga punya pacar saat itu. Plus gebetan nggak resmi. Dua atau tiga gebetan tidak resmi. Semuanya memanjakanku dengan caranya masing-masing. Rafi dengan traktiran makan dan nonton, Frank dengan keromantisan ala novelnovel Harlequin dan ciuman yang sanggup menegakkan seluruh bulu di tubuhku, dan Yori dengan segala kelucuan, keluguan, dan keikhlasannya membantuku setiap saat (antar-jemput? Beres. Komputer rusak? Beres. Kiriman makan siang? Beres).

Hidup begitu sempurna.

(Terate, 2019: 9-10)

Dalam perspektif Hurlock (1990: 247), perempuan memang dapat berpacaran dengan lebih dari satu laki-laki untuk menemukan pasangan hidup yang paling cocok. Pengalamannya berpacaran dengan sejumlah laki-laki di masa lalu membuktikan bahwa Eli adalah perempuan heteronormatif yang memiliki kemampuan menjalin hubungan percintaan dan tidak memiliki masalah kejiwaan atau fisik tertentu. Para laki-laki itu pun memperlakukannya dengan baik dan hal tersebut membuatnya senang. Meskipun memiliki karakter mandiri, sebagai perempuan biasa, ada saatnya Eli 
senang saat dimanjakan, bergantung, dan diberi perhatian oleh laki-laki.

Konstruksi masyarakat terhadap perempuan lajang yang sangat kentara di dalam novel 90 Hari Mencari Cinta adalah aksentuasi pada stigma dan mitos, bahwa bila seorang perempuan dilangkahi adiknya menikah, perempuan itu akan hidup melajang sampai akhir hayat. Namun, mitos, dalam hal ini dari budaya Jawa, juga mengganjar para lajang yang dilangkahi ini dengan 'pelipur lara' yang disebut sebagai 'pelangkah'.

"Pelangkah?"

"Iya, itu kewajiban adik yang sudah melangkahi kakaknya. Kalau kamu nggak minta, bisa bener-bener sulit jodohmu, mintalah pelangkah yang wajar. Jangan terlalu mudah, jangan terlalu sulit. Jangan terlalu mahal, tapi juga jangan murah. Itu menghina adikmu namanya." [...]

"Dan jangan sampai Tristan melangkahimu! Dilangkahi adik perempuan saja sudah gawat, dilangkahi adik laki-laki? Gawatnya dobel. Contohnya Bulik Mia tadi." (Terate, 2019: 129)

Seperti diburu waktu, perempuan dikonstruksi oleh lingkungannya untuk menikah sesegera mungkin. Gagasan yang ditanamkan dalam benak setiap orang adalah bahwa semakin berumur, peluang perempuan untuk mendapatkan pasangan pun dianggap semakin kecil. Usia 30 tahun merupakan lampu merah pengingat bagi perempuan untuk bergegas mencari suami, 'sebelum semuanya terlambat'. Stigma kelajangan ini memengaruhi mentalitas Eli menjadi tertekan dan tidak nyaman karena merasa ‘tidak laku’.

Tiga puluh tahun usiaku! Sudah tujuh tahun bekerja seperti kuda, dan yang aku punya? Hanya tumpukan tas dan sepatu. [...]

Tiga puluh. Brak! Pintu jadi PNS tertutup. Brak! Pintu ke karier model tertutup. Brak! Pintu jadi karyawan level pertama tertutup [...] dan yang paling parah:: Braaakkk! Pintu ke Mr. Perfect juga tertutup. (Terate, 2019: 12-13)

Ada apa dengan usia tiga puluh? Apa usia itu memancarkan sinyal "perawan tua" yang membuat lakilaki menjaga jarak? Meski mereka tertarik padamu, mereka akan berpikir, "Hm, cewek ini menarik, tapi kenapa dia masih jomlo? Ah, pasti dia cewek matre yang hanya doyan cowok tajir. Atau kariernya cemerlang banget dan bikin cowok minder." Itu masih mending daripada: dia pasti lesbi, dia tidak perawan lagi, dia punya masalah kejiwaan, atau dia "punya masalah dengan kesuburan".

(Terate, 2019: 14-15)

Kedua kutipan di atas merepresentasikan pandangan umum bahwa kelajangan perempuan dewasa adalah sebuah kategori sosial yang 'bermasalah', bahkan bagi mereka yang menempati posisi lajang itu sendiri. Status 
lajang akan mengundang prasangka yang membuat perempuan yang mengalaminya dilabeli secara peyoratif, mulai dari 'perawan tua', 'banyak menuntut/ materialistis', lesbian, tidak perawan lagi, sakit jiwa, hingga mandul. Eli sebagai representasi perempuan lajang menyikapi situasinya secara dilematis. Di satu sisi, ia menikmati kebebasan, kemandirian, dan prestasi, namun di sisi lain, ada perasaan tertekan, kesepian, serta keinginan untuk menuntaskan kelajangan tersebut. Usia tiga puluh seperti menjadi penanda dari ambang batas pilihan untuk masa depan.

Tiga puluh! Tiga puluh! Angka itu berdentam-dentam seperti drum. Padahal memangnya kenapa bila aku sudah tiga puluh? Aku tetap sama. Tak ada tanduk yang muncul di dahiku atau kutil di seluruh permukaan kulitku. Tapi fakta bahwa tak ada laki-laki yang beredar di orbitku, membuat semua ini tidak masuk akal. Kayaknya aku sudah menjadi ogre dalam semalam atau minimal ada aura yang menyelubungiku dan membuatku tampak seperti ... seperti apa ya? Seperti guru TK tua yang bijaksana, begitu menentramkan, enak diajak bicara, tapi sudah itu saja.

(Terate, 2019: 16)

Sebagaimana dinyatakan Hurlock (1990: 262), perempuan dewasa lajang menjadi lebih selektif memilih teman. Namun, meskipun memiliki sedikit teman, mereka dapat menjadi sangat akrab dan terbuka. Dalam novel 90 Hari Mencari Suami, Sandra dan Rosa, sahabat Eli, terungkap memiliki andil dalam membantunya mencari calon suami dengan cara membuat daftar alternatif tempat-tempat yang potensial untuk menemukan pasangan.

Mengikuti saran mereka, Eli pun pergi ke tempat fitnes yang sebelumnya tidak pernah didatangi. Ia juga bermain aplikasi Tinder untuk menemukan pasangan yang cocok. Namun, meskipun diburu waktu, perempuan ini tidak begitu saja memilih sembarang laki-laki yang ada di sekitarnya karena ia memiliki kriteria calon suaminya harus "tampan dan mapan". Dengan belajar dari pengalaman sahabat-sahabatnya, Eli pun mulai memilah hal-hal yang berpotensi baik atau buruk baginya di kemudian hari. Ia mencoba menyikapi kelajangannya dengan pandangan positif. Dalam hal ini, dapat dinyatakan bahwa Eli menghadapi stigma kelajangannya dengan cara vokasional, secara aktif ia melakukan upaya untuk mencari suami. Ia tidak berusaha bersembunyi atau menghindar dari realitas tersebut.

Usia tiga puluh kupikir menguntungkan karena aku sudah "menemukan diriku”, apa pun artinya itu. Aku tak ragu tampil 
sebagai cewek cerdas dan mandiri sebagaimana adanya diriku (waktu remaja kadang aku sengaja tampil lenjeh, manja, dan tak berdaya, berharap dengan begitu cowokcowok jatuh cinta padaku. Konyol banget). Aku tak lagi terintimidasi dengan tren dan sebagainya. Aku bahkan tak peduli bila pada hari kencanku, ada jerawat nongol di jidatku. (Terate, 2019: 200-201)

Ide di dalam kutipan di atas juga sesuai dengan teori Hurlock (1990: 255), bahwa minat perempuan untuk meningkatkan penampilan mulai berkurang menjelang umur tigapuluhan. Namun, minat tersebut dapat kembali muncul jika ada tanda-tanda ketuaan yang mendorong kecemasan individu. Hal inilah yang terjadi pada Eli. Menjelang umurnya yang ketiga puluh, ia semakin yakin untuk menjadi dirinya sendiri.

Wacana seksualitas prapernikahan, yang merupakan salah satu fokus bahasan feminisme radikal, tidak mendapat tempat dalam novel 90 Hari Mencari Suami. Meskipun sedang dalam keadaan 'terdesak' untuk mendapatkan pasangan, Eli tidak merasa dirinya harus menyerahkan diri begitu saja, ketika ada laki-laki yang ia sukai dan menyukainya. Ia berusaha menjaga diri karena dirinya masih perawan. Meskipun demikian, perempuan itu tidak benar-benar bangga dengan keadaannya. Sebaliknya, Eli kadang merasa malu karena dalam lingkungan pergaulannya, keperawanan bukan lagi merupakan hal penting yang perlu dijaga. Kondisi 'perawan' cenderung menunjukkan karakter naif dan tidak berpengalaman. Lebih jauh lagi, perempuan dewasa yang masih perawan berpotensi dilabeli sebagai perempuan 'tidak laku' atau 'tidak ada yang mau'. Stigma ini pun memperburuk citra perempuan lajang, yang diposisikan semakin inferior dalam masyarakat, karena dianggap tidak normal dan di luar kewajaran.

Dan pengakuan ketiga: sebenarnya ... aku ... eh ... masih perawan. Seratus persen. Nggak tahu deh kenapa aku malu mengakuinya. Tapi aku memang MALU mengakuinya. Rasanya kayak mengakui aku adalah manusia terakhir yang belum berevolusi. [...] cewek baikbaik harus tetap perawan sebelum menikah. (Terate, 2019: 15)

Meskipun tidak ditampilkan sebagai perempuan yang kaku atau religius, Eli memiliki prinsip untuk mempertahankan kesuciannya dan menunda hubungan seksual hingga setelah menikah nanti. Oleh karena itu, ia memilih untuk putus dengan Jay padahal mereka baru saja menjalin hubungan. Eli tidak dapat menerima prinsip laki-laki itu yang menganggap hubungan seksual sebagai 
hal yang wajar dilakukan pasangan yang sedang berpacaran (hlm. 166).

Eli juga tidak dapat menolerir lakilaki yang melakukan perselingkuhan atau kekerasan, baik secara fisik maupun verbal. Itulah sebabnya, ia memilih berpisah dengan Dewa, laki-laki yang sebenarnya dianggap memenuhi hampir semua harapannya. Dalam pandangan Eli, laki-laki itu memiliki kekurangan yang akan sangat mengganggunya jika mereka terus berhubungan bahkan menikah. Dewa dinilainya sangat posesif, pemarah, dan kurang bertanggung jawab (hlm. 297).

Selain mendapat gambaran tentang pernikahan dari sahabat-sahabatnya, Eli juga mendapat pengaruh dari para tokoh perempuan yang memang memilih untuk tidak menikah karena berbagai alasan personal. Salah satu perempuan lajang di dalam keluarganya yang memberi inspirasi adalah Bulik Mia, adik ibunya, yang menjadi dosen favorit di kampus tempatnya mengajar. Perempuan lajang lain yang menarik perhatian Eli adalah Emma, seniornya di perusahaan.

Emma lajang, dalam arti belum menikah (dan jalang). Dia punya pacar yang gosipnya sudah tinggal bersama. Umurnya 37 tahun dan nggak berniat menikah. "Kenapa harus punya mobil, kalau ada Grab yang bisa lo panggil tiap saat. Lebih murah dan nggak ribet," adalah prinsipnya. Dia bergaya hippie dan tak ada yang berani macam-macam dengannya, termasuk Vivian. (Terate, 2019: 63-64)

Prinsip praktis dan pragmatis yang diadopsi Emma yang menolak perkawinan tersebut relatif memengaruhi pandangan Eli. Ia mendapat pemahaman bahwa tanpa menikah pun, perempuan dapat merasa bahagia sepanjang hal itu memang menjadi pilihan sadarnya. Meskipun demikian, Eli melihat bahwa Emma menempuh jalan tersebut karena ada ketakutan dan trauma akibat perceraian orang tuanya.

Setelah mengupayakan berbagai cara untuk menemukan suami dalam waktu yang singkat, pada akhirnya Eli pun tiba pada kesadaran bahwa tidak semua hal yang telah ia rencanakan dapat diwujudkan sesuai keinginan. Sekalipun kehidupan telah menjadi sangat modern dan (seharusnya) lebih mudah dijalani, ada hal-hal yang tidak dapat dikendalikan manusia. Selain itu, situasi yang tidak menyenangkan menurutnya harus ditanggapi dengan sudut pandang lain, sehingga ada hikmah yang didapatkan.

Ok, untuk yang terakhir, aku sudah memutuskan untuk tidak peduli. Jadi aku tak peduli. Yeah, tentu saja aku tak peduli. Memangnya kenapa kalau aku belum punya calon saat 
adikku sudah menikah? Aku bakal jadi perawan tua? Mitos macam apa itu? Aku tak percaya. Aku. Nggak. Percaya. Tentu saja aku nggak percaya.

Lagi pula, apa buruknya jadi perawan seumur hidup? Paling kamu nggak akan punya anak, ya kan? Dan itu nggak masalah. Tak ada popok kotor atau tangan celemotan cokelat.

(Terate, 2019: 256)

Meskipun orang tua Eli tidak dikisahkan menunjukkan kecemasan berlebihan atas kelajangan putrinya itu, tetapi novel 90 Hari Mencari Suami menampilkan adanya tokoh antagonis dari pihak keluarganya. Sosok tersebut adalah Bude Nunuk yang selalu berusaha menjodohkan Eli dan mencecar gadis itu dengan peringatan "Jangan pacaran sajalah, umurmu kan sudah tiga puluh lima", "Kamu enggak takut dilangkahi? Lihat Bulik Mia. Sendirian sampai sekarang." (hlm. 128). Tokoh Bulik Mia yang disebut itu tidak muncul dan bersuara di dalam cerita namun selalu dijadikan contoh oleh Bude Nunuk untuk merepresentasikan sosok perempuan lajang yang, sekalipun mapan dan sukses dalam karir, tetap dianggap tidak utuh dan bermasalah dalam hubungan sosial. Hal ini menunjukkan bahwa perempuan baru dianggap utuh identitasnya bila telah berpasangan (dengan laki-laki) dalam institusi perkawinan.

\subsection{Perkawinan dalam Perspektif Perempuan: Menolak Wacana Penguasaan}

Eli membuat daftar "Sepuluh Alasan yang Tepat" untuk menikah (hlm. 57-58). Namun, ternyata ia hanya menemukan sembilan, yaitu: (1) agar normal seperti manusia lainnya, (2) karena menikah itu romantis, (3) ingin mengenakan gaun pengantin, (4) mendapatkan seks, (5) memiliki anak, (6) mendapatkan rumah dan mobil, (7) ada tujuan hidup, (8) mewujudkan impian romantis seperti di film Twilight, dan (9) semua teman sudah menikah. Seluruh alasan tersebut secara logis bisa jadi merupakan alasan perempuan pada umumnya untuk bersegera menikah.

Meskipun berharap segera menikah, dalam pandangan Eli, perkawinan mengubah dan membatasi langkah perempuan, karena perkawinan membebani perempuan dengan tugastugas domestik yang dilekatkan kepadanya, namun tidak pada laki-laki. Perempuan akan disibukkan oleh anakanak sehingga tidak dapat melakukan kebiasaan-kebiasaan dan pergaulan yang menyenangkan saat masih lajang.

Perempuan lebih menyebalkan lagi. [...] mereka cuma mengobrolkan 
popok, sale susu, atau gemblungnya asisten rumah tangga mereka. Mereka tak lagi punya waktu untuk diajak nongkrong di kafe atau nonton film $A B G$ sambil jejeritan. Norak, kata mereka. [...] Andai mereka mau nongkrong ngopi pun, pasti hanya sebentar karena selalu ada krisis, "anakku demam”, "ibu mertuaku mau datang, inspeksi mendadak", "duh, nanny-ku mau pulang kampung”, dan seterusnya. Nongkrong lebih lama sedikit selalu diselingi telepon-telepon untuk mengecek ketersediaan popok atau susu. (Terate, 2019: 16-17)

Kutipan tersebut menunjukkan ketidaksukaan Eli pada gambaran perempuan berkeluarga, yang mungkin akan melekat padanya juga jika ia menikah kelak. Ia tidak ingin kebebasannya bersenang-senang dikekang. Situasi ini sejalan dengan kajian Hurlock (1990: 266) yang menguraikan bahwa perempuan masa kini mengharapkan menjadi istri dan ibu, namun menolak konteks tradisional dari kedua peran itu. Yang Eli harapkan sebenarnya adalah berada dalam institusi perkawinan yang menempatkan istri dan suami pada posisi sederajat. Mereka akan berbahagia dan menanggung seluruh beban rumah tangga bersama, yang berarti Eli ingin tetap bekerja. Oleh karenanya, ia merasa heran mendengar keinginan Lisa, adiknya, yang merasa baik-baik saja dengan menjadi ibu rumah tangga setelah menikah.

"Lis, dengar aku. Kalau kamu menikah, kamu nggak akan punya kesempatan berkarier atau kuliah setinggi-tingginya. Puas-puasin dulu masa mudamu."

"Tapi aku sudah puas," Alisa terdengar mantap. "Aku sudah bilang, aku mungkin bisa kuliah di Jepang. Tapi kalau tidak bisa pun, tidak apa-apa. Kurasa aku bakal hepi-hepi aja jadi ibu rumah tangga."

Mengejutkan! Oh, Kartini pasti menangis mendengarnya.

(Terate, 2019: 34)

Dalam bayangan Eli, perkawinan seharusnya menyenangkan dan adil bagi kedua belah pihak. Ia juga membayangkan akan memperlihatkan kesenangan yang didapatkannya dalam perkawinannya kelak melalui media sosial, sebagaimana yang saat ini lazim dipamerkan oleh pasangan 'yang berbahagia'.

Setelah menikah dia dan suaminya bikin usaha bareng, backpacking sepuluh hari di Australia naik van, umroh bareng, bikin rumah sendiridan tiap tahapnya mereka upload di Instagram. Rumahnya biasa-biasa aja, tetapi entah gimana banyak yang nge-like, lalu mereka punya anak dan blam! Pada usia tiga tahun anak ini udah femes di Instagram karena fotonya menurut orang-orang imut banget. Bah, semua anak kecil begitu juga, kali! 
Oh, astaga, berat kuakui, tapi $A K U$ INGIN SEMUA itu. Soalnya mereka PUNYA semua itu dan aku nggak punya! Persetan. (Terate, 2019: 59)

Kutipan tersebut menunjukkan bahwa keluarga normatif membutuhkan rumah sebagai latar kehidupannya. Bila mobil menjadi simbol status utama bagi remaja, Packard dalam Hurlock (1990: 257) menjelaskan bahwa pada orang dewasa, rumahlah yang menjadi simbol status penting karena merupakan tempat untuk memamerkan 'budaya' dan kekayaannya. Di dalam rumah, orang dapat memamerkan barang, buku-buku, kristal, lukisan, pakaian, dan sebagainya. Mobil tidak dapat menjadi lahan pameran materi seperti itu. Eli meyakini bahwa materi memang diperlukan untuk membangun kebahagiaan. Namun, dari pengalaman Sandra, sahabatnya, ia menemukan bahwa materi tidak menjamin kebahagiaan dan kelanggengan sebuah perkawinan.

Awalnya aku mendambakan pernikahan, tetapi setelah apa yang menimpa dua temanku, aku tak yakin lagi. Sebenarnya, untuk apa sih pernikahan itu? Lihat Sandra. Orang-orang mengatakan mereka pasangan sempurna, tampan dan cantik, uang tak kurang, sama-sama pintar, dan masing-masing punya karier cemerlang. Tetapi lihat,
Sandra tidak bahagia. Kurasa Aron pun tidak. (Terate, 2019: 185)

Eli pun mengamati pengalaman kehidupan pernikahan Pak Dion dan $\mathrm{Bu}$ Mimi, kliennya. Sejak pertemuan pertama, terlihat bahwa Pak Dion bersikap sangat sabar menghadapi perilaku dan kata-kata istrinya yang sangat pahit dan sinis. Eli mengira laki-laki itu berusaha memakluminya karena $\mathrm{Bu}$ Mimi menderita sakit kanker. Ternyata di kemudian hari, Eli mengetahui bahwa di masa lalu Pak Dion pernah berselingkuh dan kemudian diusir oleh sang istri. Namun, ketika ia terpuruk, Bu Mimi bersedia menerima suaminya kembali.

Aku teringat Pak Dion dan Bu Mimi. Cinta berarti saling menerima. Cinta berarti memaafkan. Apakah aku harus memaafkan juga? Tunggu! Memangnya aku cinta padanya? [...]

Apakah aku akan memaafkan pasanganku bila dia selingkuh? Tidak! Aku tak bakal memaafkan pengkhianatan semacam itu. Aku menghela napas. Kurasa setiap orang punya nilai-nilai sendiri menyangkut hubungan percintaan. Apa yang bisa diterima dan apa yang bisa dimaafkan.

(Terate, 2019: 281)

Eli juga mendapat pembelajaran dari hubungannya dengan Dewa. Ia memang menyukai tampilan fisik Dewa dan 
kemapanannya yang sangat sesuai dengan ekspektasi. Namun, Eli tidak dapat menerima karakter kasar, penindas, dan posesif pada laki-laki itu yang jauh di luar dugaannya. Meskipun ia sempat berharap Dewa menjadi pasangannya di kemudian hari, pada akhirnya ia menyadari tidak ingin menghabiskan masa depan dengan laki-laki yang berpotensi menyakitinya itu. Terlebih lagi, Dewa ternyata meyakini stigma buruk terhadap perempuan lajang.

"Jadi kamu nggak mau berkompromi?" Dewa menatapku tajam. Menusuk.

Hah, siapa yang tidak mau berkompromi? Bukannya kamu?

"Pantas saja kamu tidak menikah sampai saat ini. Tak ada laki-laki yang mau dengan perempuan keras kepala sepertimu."

Apa? Aku kaget. Tanpa sadar kutentang matanya. Mata itu menyala dengan amarah. Tetapi anehnya, aku tidak takut.

"Oya? Aku nggak peduli. Lebih baik aku tak menikah daripada dipasung laki-laki egois sepertimu."

(Terate, 2019: 297)

Eli, yang sebelumnya percaya bila Dewa menyukai dirinya apa adanya, merasa terkejut karena laki-laki berpendidikan tinggi pun ternyata percaya pada stigma perempuan lajang. Karena telah memiliki kriteria tentang sebuah perkawinan yang setara dan dapat membuatnya bahagia, Eli pun memilih untuk memutuskan tidak lagi berhubungan dengan laki-laki itu. Ia menolak untuk berada dalam posisi dikuasai, karena yang diinginkannya adalah perkawinan dalam posisi setara.

Berbeda dengan Sandra yang tidak menyukai anak dalam perkawinannya, Eli menganggap bahwa keluarga yang ia inginkan adalah keluarga dengan anakanak di dalamnya.

Ah, aku pasti akan mengundangnya untuk memotret bayiku bila aku punya bayi suatu hari nanti. Hah, tunggu sebentar. Apakah barusan aku memikirkan untuk punya bayi? Aku dan Dimi belum membicarakannya, tetapi kurasa diam-diam ada kesepakatan di antara kami; bayi akan kami terima dengan sukacita bila dia memang tiba. (Terate, 2019: 358)

Pada akhirnya, Eli mendapatkan harapannya, yaitu laki-laki yang mencintainya dan ia cintai, Dimi. Meskipun Dimi tidak memenuhi kriteria 'tampan dan mapan' yang disyaratkan dan 'hanya' bekerja sebagai PNS di kantor catatan sipil, Eli merasa bahagia. Pernikahan mereka memang terjadi setelah melebihi batas 90 hari yang ditetapkannya dulu, namun Eli tetap bersyukur karena telah mendapatkan banyak pengalaman berharga. Dia merasa pernikahan membawa kebaikan dan 
kebahagiaan asal dilakukan dengan orang yang tepat, di saat yang tepat, dengan alasan yang tepat (Terate, 2019: 286).

Dari pembahasan bagian ini, terungkap bahwa perkawinan bagi perempuan tidak seharusnya dilakukan karena perasaan takut (dilangkahi atau dilekati stigma) melainkan sebagai pilihan sadar dari individu yang menjalaninya. Konsep perkawinan yang ideal adalah yang memosisikan perempuan dan lakilaki yang ada di dalamnya pada kedudukan setara.

\section{Penutup}

Hasil penelitian terhadap novel metropop 90 Hari Mencari Suami menunjukkan bahwa dalam situasi modern sekalipun, kelajangan masih merupakan hal yang tidak wajar dan cenderung dianggap aneh oleh masyarakat jika dipilih sebagai jalan hidup oleh perempuan dewasa. Hal tersebut terjadi karena perempuan telah dikonstruksi secara sosial, di antaranya melalui mitosmitos. Perempuan lajang dianggap sebagai mahluk yang tidak utuh karena tidak memiliki pasangan (laki-laki). Namun, terungkap bahwa setelah menempuh cara vokasional, protagonis perempuan mendapatkan kesadaran jika mitos itu tidak benar. Sebagai perempuan dewasa, ia memiliki hak untuk menentukan jalan hidup sebagaimana yang dimiliki oleh laki-laki.

Perkawinan juga tidak seharusnya dimotivasi oleh perasaan takut (dilangkahi atau dilekati stigma), melainkan sebagai pilihan sadar dari individu yang menjalaninya. Konsep perkawinan yang ideal adalah yang memosisikan perempuan dan laki-laki yang ada di dalamnya pada kedudukan setara.

Sebagai implikasi dari penelitian ini, terungkap bahwa seperti dalam sebagian besar karya fiksi kontemporer Indonesia lainnya, kelajangan tidak benar-benar dirayakan atau menjadi pilihan protagonis perempuan. Pada akhirnya, perempuan lajang tetap kembali berada di bawah konstruksi patriarki dengan menerima perkawinan sebagai alasan untuk menghindari stigma.

\section{Daftar Pustaka}

Beauvoir, S. d. 2016. Second Sex: Fakta dan Mitos. Jakarta: PT. Buku Seru.

Djajanegara, S. 2003. Kritik Sastra Feminis: Sebuah Pengantar. Jakarta: Gramedia Pustaka Utama.

Fahmi, R. F. A., R. . 2020. Kesetaraan Perempuan dan Polemik Budaya Patriarkal dalam Novel Cinta Suci Zahrana. Deiksis, 7(1), 36-45.

Greitemeyer, T. 2009. Stereoptypes of Singles: Are singles what we 
think? European Journal of Social Psychology, 39, 368-383.

Humm, M. 2007. Ensiklopedia Feminisme (M. Rahayu, Trans.). Yogyakarta: Fajar Pustaka Baru.

Hurlock, E. B. 1990. Psikologi Perkembangan: Suatu Pendekatan Sepanjang Rentang Kehidupan. Jakarta: Erlangga.

Intan, T. 2020. Resiliensi Perempuan Lajang dalam Metropop GanjilGenap Karya Almira Bastari. Adabiyyāt: Jurnal Bahasa dan Sastra, 4(1), 47-65.

Intan, T. 2021. Perempuan Lajang dan Perjodohan dalam Novel Jodoh Terakhir Karya Netty Virgiantini. Alinea: Jurnal Bahasa Sastra dan Pengajaran, 10(1), 1-14.

Intan, T., Elga Ahmad Prayoga. 2021. Strategi Kebertahanan Perempuan Lajang dalam Novel Cincin Separuh Hati Karya Netty Virgiantini. Fonema: Edukasi Bahasa dan Sastra Indonesia, 4(1), 1-17.

Major, B., O'Brien, L.T. 2005. The Social Psychology of Stigma. Annual Review of Psychology, 56(393421).

Mami, L. S. 2015. Harga Diri, Dukungan Sosial, dan Psychological Well Being Perempuan Dewasa yang Masih Lajang. Persona, Jurnal Psikologi Indonesia, 4(3), 216-224.

Septiana, E., Syafiq, M. 2013. Identitas "Lajang" (Single Identity) dan Stigma: Studi Fenomenologi Perempuan Lajang di Surabaya. Jurnal Psikologi Teori \& Terapan, 4(1), 71-86.
Taylor, A. 2012. Single Women in Popular Culture: The Limits of Post-feminism. New York: Palgrave Macmillan.

Terate, K. 2019. 90 Hari Mencari Suami. Jakarta: PT. Gramedia Pustaka Utama.

Widianti, N. R., S.A.; Labibah, S.; Solihin, N. 2020. Representasi Perjuangan Perempuan dalam Novel Wedding Agreement karya Mia Chuz. Muwazah Jurnal Kajian Gender, 12(1), 53-70.

Wijayanti, E. 2019. Ulasan Novel 90 Hari Mencari Suami Karya Ken Terate. https://www.fimela.com/lifestylerelationship/read/4137919/ulasannovel-90-hari-mencari-suamikarya-ken-terate diakses tanggal 14 September 2020

Wiyatmi. 2012. Kritik Sastra Feminis: Teori dan Aplikasinya dalam Sastra. Yogyakarta: Ombak. 
